\title{
Exploring Civic Ecology Practice: Composting program in Subang Jaya
}

\author{
Sati Mazwin Kamaruddin ${ }^{1}$, Alamah Misni2 ${ }^{2}$ Puziah Ahmad ${ }^{3}$ Mohd Hafiz Sharif ${ }^{4}$ \\ ${ }^{1}$ Centre of Studies Town and Regional Planning, ${ }^{2}$ Centre of Studies Landscape Architecture, \\ ${ }^{3}$ Centre of Studies Town and Regional Planning, Faculty of Architecture Planning and Surveying, \\ Universiti Teknologi MARA, Malaysia \\ ${ }^{4}$ Majlis Perbandaran Subang Jaya, Malaysia
}

Sitim065@uitm.edu.my, Alama884@uitm.edu.my, Puzia892@uitm.edu.my, Hafiz.shariff@mpsj.gov.my

Tel +6 0173451987

\begin{abstract}
Active engagements in ecology practices are platforms which lead to good ecological behaviour and consciousness (Kamaruddin et.al., 2013). This study aims to explore urban community stewardship or civic ecology practice of doing composting in an urban municipality, i.e. Subang Jaya Selangor, Malaysia in the context of practice theory (Schatzki, 2000). The variables were analysed using the chi square test of independence and factor analysis procedure. The findings highlight how elements, such as competencies, meanings and physical resource, define the practice and support urban stewardship. Family and friendship networking, collaboration with others and civic consciousness were crucial in motivating the participants and support program sustainability.
\end{abstract}

Keywords: Environmental stewardship; Civic ecology; Sustainable waste management

eISSN: 2398-4287 @ 2019. The Authors. Published for AMER ABRA cE-Bs by e-International Publishing House, Ltd., UK. This is an open access article under the CC BYNC-ND license (http://creativecommons.org/licenses/by-nc-nd/4.0). Peer-review under responsibility of AMER (Association of Malaysian Environment-Behaviour Researchers), ABRA (Association of Behavioural Researchers on Asians) and cE-Bs (Centre for Environment-Behaviour Studies), Faculty of Architecture, Planning \& Surveying, Universiti Teknologi MARA, Malaysia. DOI: https://doi.org/10.21834/e-bpj.v4i12.1772

\subsection{Introduction}

Civic ecology can be defined as the study of individual, community, and environmental outcomes and interactions of such practices with communities, governance institutions, and ecosystems". It is considered as a "community software" approach to sustainability (Krasny and Tidball, 2015). Civic ecology practice is defined as "local environmental stewardship actions to enhance green infrastructure and community well being in cities and other human-dominated systems" (Krasny and Tidball, 2018). The neighbourhood composting program, initiated by the local authority in Subang Jaya, Selangor (Majlis Perbandaran Subang Jaya), is one of the first urban communities to implement neighbourhood composting programs. MPS $J$ is the first Local Authority in Selangor Malaysia to set up a Bio Mass centre within its neighbourhood. This step is an attempt at sustainable waste management (SWM), one of the most challenging environmental problems and potential renewable sources of energy. The purpose of this research is to explore practice theory as an approach to studying urban ecological stewardship. According to Krasny and Tidball (2015), practice theory focuses on elements of civic ecology practice such as competencies, meanings, motivation, and physical resources. The findings would add to the recent literature on community-based stewardships or public ecology practices (Schoor and Scholtens, 2015; Krasny et al., 2018). These can lead to practical proposals and priorities while assisting the Municipality's actions towards the neighbourhood's environmental program effectiveness. At the community level, communities can make more informed and viable choices in their daily lives. This study utilises a

eISSN: 2398-4287 @ 2019. The Authors. Published for AMER ABRA cE-Bs by e-International Publishing House, Ltd., UK. This is an open access article under the CC BYNC-ND license (http://creativecommons.org/licenses/by-nc-nd/4.0). Peer-review under responsibility of AMER (Association of Malaysian Environment-Behaviour Researchers), ABRA (Association of Behavioural Researchers on Asians) and cE-Bs (Centre for Environment-Behaviour Studies), Faculty of Architecture, Planning \& Surveying, Universiti Teknologi MARA, Malaysia. DOI: https://doi.org/10.21834/e-bpj.v4i12.1772 
cross-sectional survey utilizing questionnaires to 351 respondents. The respondents fit the criteria relevant to the aim of this study. We applied statistical procedures for evaluating and validation of the data and interpret the findings.

\subsection{Literature Review}

Practice theory views practices as the core unit of analysis and thus offers a middle ground between individual agency or behaviour and social or institutional structures (Reckwitz, 2002; Hargreaves, 2011). It suggests that to foster more environmentally friendly consumer and other actions, we should no longer focus on "individuals' attitudes, behaviours, and choices, but instead on how practices form, how they are reproduced, maintained, stabilized, challenged and ultimately killed-off; on how practices recruit practitioners to maintain and strengthen them through continued performance, and on how such practitioners may be encouraged to defect to more sustainable practices" (Hargreaves, 2011). In prioritizing practices over individuals, practice theory claims that features of individuals, such as the activities in which they engage, their skills, interactions with others, and interpretations or meanings, arise from their participation in social practices (Cetina et al., 2000). Practice theory argues that the locus of the social is in practices, i.e., networks of relationships between people, things, and activities. In this way, practice theory is more of a worldview which focuses on social structures as determining human behaviours, and postmodern approaches, which emphasize human agency (Reckwitz, 2002). Practices are composed of multiple elements and their interactions. However, practice theory scholars diverge on the aspects of practice worthy of study (Gram-Hanssen, 2011). For example, authors variously describe the elements of holding practices together as understandings, procedures, engagement, and items of consumption (Warde, 2005); practical knowledge, rules, and general beliefs (Schatzki, 2002); sayings, doings, and relating (Kemmis and Mutton, 2012); Practice theory adds to these explanations by helping us understand the factors involved in the emergence and growth of new social processes such as grassroots or social innovations (Seyfang et al., 2010) as communities are becoming more environmentally concerned (Hashim et al., 2016). In this study, we ask how do elements such as competencies, meanings, and physical resources of a community's composting activities relate to each other and contribute to defining the civic ecology practice of study?

The case study area selected is urban Subang Jaya, Selangor, a city under MPSJ's administration. The area is about $161.8 \mathrm{~km} 2$, and this city has a high population of 642,100 in 2015. There are approximately more than 90,000 housing units in the MPSJ area, which comprise of terrace houses, flats, semi-detached houses, and bungalows. MPSJ has received international recognition such as the Green Apple Award, i.e., the Biomass Way category in 2014, for its green efforts. The community composting program in Subang Jaya started in 2010 with 152 residents' participation and currently has increased to 700 or more resident involvements. MPSJ encourages residents to practice composting as a green activity by supplying free composting bins to the individual household that requests the containers. The public can separate organic waste on their own and help minimize the waste generation by practicing home composting. From the year 2010 until 2017, more residents participate and practice composting, and this is a good indicator of increasing public engagement in the Biomass Town Project (Kamaruddin et al., 2017). Currently, some of the projects covered under the MPSJ's biomass initiative are a Green waste composting project, a Food waste composting project; a Vermicomposting project; a Communal composting project.

\subsection{Methodology}

This study aims to explore the elements of civic ecology practice of residents involved with green composting. The main research question was how do aspects of practice theory such as competencies, motivations for participation, meanings, and physical resource of a community's composting activities relate to one another, and how does this define the civic ecology practice of green composting in the case study area. This study uses a cross-sectional survey utilizing questionnaires as the research instrument. The sample household of 351 respondents was selected based on a stratified sampling method, and the list was obtained from the municipality. The main criteria of the sample household are that it is located within the MPSJ administrative area, has requested the composting bin from MPSJ, and currently practicing green composting. The researchers obtained 351 willing households to answer the questionnaire. The questionnaire has two parts. The first part of the survey receives data about residents' socio-demographic background while the second part contains questions about constructs of respondents' competencies, meanings, physical resources, and motivations in practicing green waste composting. The items had 5 points Likert like scale responses. The questions formed the predictors and outcome variables and were based on previous studies of green behaviour and elements of practice theories (Kamaruddin et al., 2015; Krasny et al., 2015). Reliability analysis of the questionnaire relevant to the questions in the second part was conducted, and the result indicates overall internal reliability (Cronbach's alpha $=0.711$ ). The estimation of construct validity about the four constructs/elements of practice was performed using factor analysis (Goodwin, 1999). This was necessary to extract which variables were deemed most correlated and significant (Kline, 1994).

\subsection{Data Analysis and Findings}

This study seeks to gain an insight into respondents composting practice and the level of association and correlation between practice (in this case, household green composting as the outcome variable) with elements of socio-demography (age, income, education etc) and the aspects of constructs of practice (such as competency, meanings and physical resource as the predictor variables). Application of quantitative inferences such as cross-tabulation and correlation analysis of the variables can contribute to a better understanding of the relationships between the variables (independent or otherwise; positive, neutral or negative; weak or strong) and enable future prediction assessment (Frey et al.,1999). 
3.1.1 Socio-demographic profile and association to composting practice

Table 1 indicates the data of the respondents' socio-demographic profile. The majority of the respondents live in the landed property $(98 \%)$ and are semiprofessionals or professionals $(86.6 \%)$, home-based employed or retired $(12.2 \%)$, and students $(1.1 \%)$. The majority of the respondents are middle-income household earners who earn between RM3000 - RM10,000 a month (72.6\%). 21.7\% are those that earn more than RM10,000, while the remaining $5.7 \%$ earn less than RM3000 a month. A majority of the respondents (71.8\%) have resided in Subang Jaya for more than 11 years, followed by $18.5 \%$ of the respondents who have lived there for $6-10$ years while the rest (9.7\%) lived there for less than six years.

Table 1: Respondents' Socio-Demographic Profile

\begin{tabular}{|c|c|c|}
\hline Element & $\begin{array}{r}\text { Number of } \\
\text { Respondents }\end{array}$ & Percentage \\
\hline \multicolumn{3}{|l|}{ Gender } \\
\hline Female & 173 & 49.3 \\
\hline Male & 178 & 50.7 \\
\hline Total & 351 & 100.0 \\
\hline \multicolumn{3}{|l|}{ Type of property } \\
\hline Landed & 344 & 98.0 \\
\hline Apartment & 7 & 2.0 \\
\hline Total & 351 & 100.0 \\
\hline \multicolumn{3}{|l|}{ Occupation } \\
\hline Student & 4 & 1.1 \\
\hline $\begin{array}{l}\text { Semi Professional/ } \\
\text { Professional Employed }\end{array}$ & 304 & 86.6 \\
\hline Home Based Employed & 17 & 4.8 \\
\hline Retired & 26 & 7.4 \\
\hline Total & 351 & 100.0 \\
\hline \multicolumn{3}{|l|}{ Income } \\
\hline Below 3000/month & 20 & 5.7 \\
\hline $3000-5000 /$ month & 91 & 25.9 \\
\hline $5000-10,000 /$ month & 164 & 46.7 \\
\hline More than $10,000 /$ month & 76 & 21.7 \\
\hline Total & 351 & 100.0 \\
\hline \multicolumn{3}{|c|}{ Length of stay in Subang Jaya } \\
\hline $1-5$ years & 34 & 9.7 \\
\hline $6-10$ years & 65 & 18.5 \\
\hline $11-20$ years & 155 & 44.2 \\
\hline 21 years and above & 97 & 27.6 \\
\hline Total & 351 & 100.0 \\
\hline
\end{tabular}

The data from the survey highlighted that the majority of the respondents do compost daily $(58.4 \%)$, followed by weekly $(21.1 \%)$ and monthly (12.3\%). A majority of the respondents $(57 \%)$ report that they produce an average of $1-250 \mathrm{gm}$ of compost weekly, followed by $20.2 \%$ of the respondents providing $251-500 \mathrm{gms}$ of compost weekly. Upon evaluation of the data, a majority of the respondents reported that they have much knowledge in composting (90\%) while the rest have some or less experience. Table 2 and Figure 1 highlight the respondents' composting frequencies and the volume of compost produced.

Table 2: Respondents Composting Frequencies

\begin{tabular}{|l|r|r|}
\hline How frequent do you do Composting? & $\begin{array}{c}\text { Number of } \\
\text { Respondents }\end{array}$ & Percentage \\
\hline Daily & 205 & 58.4 \\
\hline Weekly & 74 & 21.1 \\
\hline Monthly & 43 & 12.3 \\
\hline Every 6 Months & 17 & 4.8 \\
\hline Yearly & 12 & 3.4 \\
\hline Total & 351 & 100.0 \\
\hline
\end{tabular}




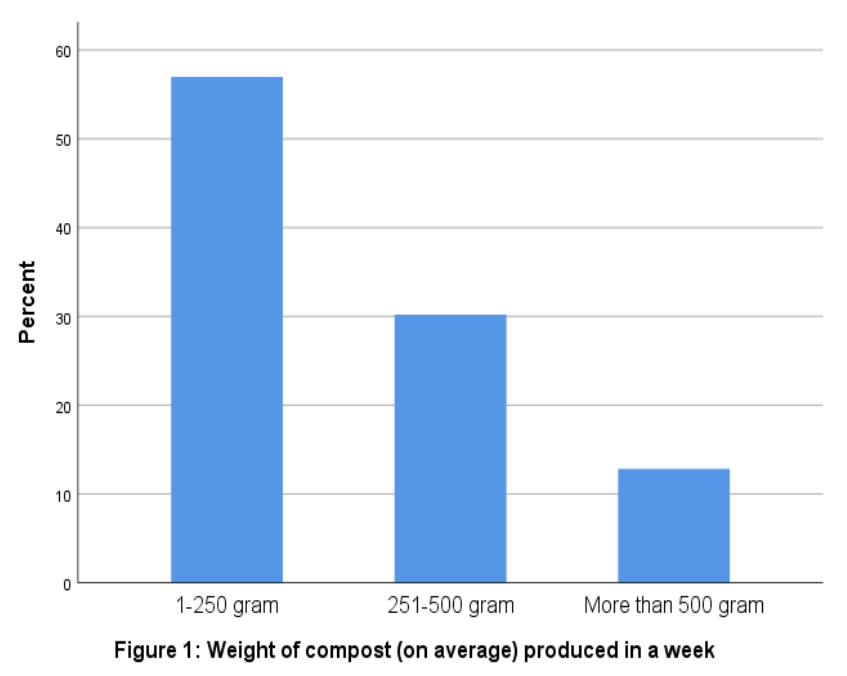

Table 3: Chi square Test of Independence between Socio-demography Variables and Frequency of Doing Composting

\begin{tabular}{|l|l|l|l|l|}
\hline $\begin{array}{l}\text { How often do you do composting? } \\
\text { Cross tabulation }\end{array}$ & Value & df & $\begin{array}{l}\text { Significance } \\
(\mathrm{p})\end{array}$ \\
\hline${ }^{*}$ Length of Stay in Subang Jaya & Pearson Chi-Square & $24.439^{\mathrm{a}}$ & 12 & .018 \\
\hline \multicolumn{2}{|l}{$\mathrm{P}<0.05$ is statistically significant } \\
\hline
\end{tabular}

An analysis of the relationship between socio-demography variables and practice of composting was conducted using the chi-square test of independence. The results are shown in Table 3 . The findings indicate that there is a significant association $(p<0.05)$ between doing composting with 'length of stay'. This finding states that "length of stay" is significantly associated with composting as a green practice. This is consistent with a previous study by the researchers who looked at recycling participation (Kamaruddin et al., 2015). However, other socio-demographic variables (income, education, profession, age, homeownership, or type of residence) did not have enough evidence to suggest an association with doing green composting.

\subsubsection{Correlations of Constructs}

The following sections describe the respondents composting activities and highlight the findings of an analysis of the correlations of the constructs (predictor variables) to the civic ecology practice in focus (outcome variable). In addition to technical competencies of sustaining a green behaviour, Krasny et al. (2015) posit that social and communication skills are equally important, and this includes the ability to build collaborations with other stakeholders, mobilizing others, and expanding the practice through various means including social networking. The evidence in this study indicates that almost all (99\%) reported that they collaborate with other stakeholders in the composting program. This includes collaboration with the local authority, schools, and commercial organizations. $93.4 \%$ of the respondents also reported that they help to train others to do composting while $99 \%$ reportedly learn how to do composting from their family members, neighbours, or social media group (Refer to Table 4).

Table 4: Respondents Source of Knowledge of Composting

\begin{tabular}{|l|r|r|}
\hline $\begin{array}{l}\text { If there are no trainers, where did you learn } \\
\text { how to do composting? }\end{array}$ & $\begin{array}{l}\text { Number of } \\
\text { Respondents }\end{array}$ & \multicolumn{2}{l|}{\begin{tabular}{l} 
Percentage \\
\hline Family
\end{tabular}} \\
\hline Neighbours & 101 & 16.0 \\
\hline Local Authority & 60 & 28.8 \\
\hline $\begin{array}{l}\text { Internet WhatsApp /FB/IG social media } \\
\text { group }\end{array}$ & 131 & 17.1 \\
\hline TV/ magazines & 3 & 37.3 \\
\hline Total & 351 & .9 \\
\hline
\end{tabular}

Before assessing the correlation of the construct 'competency' with 'doing composting,' the researcher first established validity for the 'competency' construct using factor analysis procedure in SPSS V25 and used principal components (PC) method of extraction. PCA is a procedure that transforms several correlated variables into a smaller set. In social science studies, loadings of more than 0.6 are considered high and reveal the critical variables of the construct (Kline, 1994). The procedure on the construct 'competency' brought forth two components with a cumulative $74.87 \%$ variance and met the KMO-Bartlett's test of sphericity $(p=0.000)$. Referring to the scree plot of Eigenvalue $>1$ further confirms two principal components. The results are shown in Table 5. 
Table 5: Factor Analysis of 'Competency' Construct

\begin{tabular}{|l|r|r|}
\multicolumn{1}{c|}{} & $\begin{array}{c}\text { Component } 1 \\
\text { (Training) }\end{array}$ & $\begin{array}{c}\text { Component } 2 \\
\text { (Communication) }\end{array}$ \\
\cline { 2 - 4 } \multicolumn{1}{c|}{ Are there trainers provided (by MBSJ) to teach how to do composting (Yes/No) } & .637 & Loadings \\
\hline I train others in composting (Yes/No) & .887 & -.237 \\
\hline I organize training with other neighbours (Yes/No) & .867 & .355 \\
\hline I collaborate with others (Yes/No) & .873 & .376 \\
\hline I am able to communicate about composting (Ranked Very Much) & .140 & .377 \\
\hline Having patience and understanding composting (Ranked Very Much) & .145 & .825 \\
\hline Extraction Method: Principal Component Analysis. & .774 \\
\hline
\end{tabular}

Rotation Method: Varimax with Kaiser Normalization.

The findings from the procedure indicate that there are five variables with loadings of 0.6 and above. The positive loadings in the first component i.e. "Training" indicate that the variable "training others," "organising training," and collaboration with others" are positively correlated and suggest that these variables have a substantial effect on that construct. In the second component i.e."Communication" the positive loadings point towards a positive correlation for variables "ability to communicate about composting" and "having patience and understanding," which indicate a high impact on the "competency' dimension. High loading of variables can be interpreted as determiners to that construct (Holland, 2019).

Using factor analysis, the researchers established the construct validation for the 'meanings' dimension. The loadings from PC extraction are as shown in Table 6. This procedure on the construct 'meaning' brought forth four components with a cumulative $59.96 \%$ variance and met the KMO-Bartlett's test of sphericity $(\mathrm{p}=0.000)$. We refer to the components as "Similar Interest", "Waste to resource", "Benefit to the Environment" and "Benefit to plants". The four elements revealed nine variables that loaded more than 0.6 (considered in social studies as high scores by Kline, 1994) are " composting is an enjoyable hobby", "connecting people with the same interest", "supporting local authority's goal", " the concern about waste going to landfill", 'composting is beneficial to the environment", "composting is a source of supplement to the garden", "composting is transforming waste to resource", "composting is a way to avoid food being wasted", composting lowers carbon footprint" and supporting local authority's goal". These variables indicate the important variables or determiners associated with the construct of 'meaning.'

Table 6: Factor Analysis of 'Meaning' Construct

\begin{tabular}{|c|c|c|c|c|}
\hline & \multicolumn{4}{|c|}{ Components } \\
\hline & $\begin{array}{c}1 \\
\text { "Similar } \\
\text { Interest" }\end{array}$ & $\begin{array}{c}2 \\
\text { "Waste to } \\
\text { resource" }\end{array}$ & $\begin{array}{c}3 \\
\text { "Benefit to } \\
\text { Environment" }\end{array}$ & $\begin{array}{c}4 \\
\text { "Benefit to } \\
\text { plants" }\end{array}$ \\
\hline & Loadings & Loadings & Loadings & Loadings \\
\hline Are you concerned about waste going to a landfill & -.156 & -.094 & .758 & .116 \\
\hline Is composting beneficial to the environment & .141 & .066 & .776 & .103 \\
\hline It is beneficial to the environment & .311 & .532 & .461 & .151 \\
\hline It reduces food waste from ending up in landfills & .477 & .282 & .465 & -.304 \\
\hline It is a source of supplement for my plants/garden & .163 & .070 & .135 & .785 \\
\hline It is a source of income & .576 & -.008 & .133 & .123 \\
\hline It is an enjoyable hobby & .644 & .420 & -.044 & -.084 \\
\hline Saving the environment & .269 & .440 & .378 & .404 \\
\hline Transforming waste to resource & .199 & .762 & .040 & .161 \\
\hline A way to avoid food being wasted & .006 & .797 & -.052 & .115 \\
\hline Lowers carbon footprint & .166 & 290 & .068 & .771 \\
\hline Connecting people with the same interest & .663 & 203 & -.050 & .172 \\
\hline Supporting the local authority's goal & .674 & .017 & .045 & .356 \\
\hline
\end{tabular}

Extraction Method: Principal Component Analysis.

Rotation Method: Varimax with Kaiser Normalization.

Table 7: Factor Analysis of 'Motivation' Construct

\begin{tabular}{|c|c|c|c|}
\hline & \multicolumn{3}{|c|}{ Components } \\
\hline & $\begin{array}{c}1 \\
\text { "Family } \\
\text { Members } \\
\text { Influence" }\end{array}$ & $\begin{array}{c}2 \\
\text { "Reduce Waste } \\
\text { to Landfill" }\end{array}$ & $\begin{array}{c}3 \\
\text { "Fun" }\end{array}$ \\
\hline Have a Civic Conscious (desire to improve the community) & .103 & .208 & .658 \\
\hline Have an Interest/Hobby & .491 & .311 & .257 \\
\hline Follow Family Member's suggestion & .757 & .117 & .010 \\
\hline To gain financial incentive & .505 & .189 & .037 \\
\hline To influence policy outcomes & .690 & .250 & .238 \\
\hline I enjoy working with like-minded people & .753 & .276 & .235 \\
\hline I have fun with my family doing composting & 242 & .095 & .771 \\
\hline I can create friendships with others doing composting & 665 & .358 & .144 \\
\hline I can reduce the carbon footprint of the neighbourhood & 377 & 601 & 193 \\
\hline I can reduce the amount of trash going to landfills & .096 & .754 & .313 \\
\hline
\end{tabular}




\begin{tabular}{|c|c|c|c|}
\hline I can make the neighbourhood a better place to live & .287 & .377 & .517 \\
\hline I enjoy working with like-minded people & .574 & -.006 & .449 \\
\hline Can continue to network & .622 & -.020 & .498 \\
\hline Can continue creating friendships & .751 & .223 & .227 \\
\hline Can continue to reduce the carbon footprint of the neighbourhood & .065 & .515 & .639 \\
\hline Can continue to reduce the amount of trash going to landfills & .340 & .802 & -.058 \\
\hline Can continue to make the neighbourhood a better place to live & .230 & .604 & .349 \\
\hline
\end{tabular}

Extraction Method: Principal Component Analysis.

Rotation Method: Varimax with Kaiser Normalization.

The correlated variable loadings from the PC extraction method for the construct 'motivation' revealed three components i.e. "Family members influence", "Reduce waste to landfill" and "Fun" as shown in Table 7. The cumulative variance is $57.86 \%$, and the factor analysis met the KMO-Bartlett's test of sphericity $(\mathrm{p}=0.000)$. The three components revealed twelve variables that loaded more than 0.6 . This threshold score is used in social studies to select the variables that are important to the dimension (Kline, 1994). The positive loadings in the three-component indicate that the critical variables associated with 'motivation' in doing composting include "following suggestions from family members", "creating friendships and networking"; "that composting can reduce carbon footprint and trash to the landfill"; "composting can continue to make the neighborhood a better place to live in" and that "composting can be fun" and the practice is "undertaking a civic consciousness". These variables form reliable indicators to the construct of 'motivation' to composting.

\begin{tabular}{l|r|r}
\multicolumn{2}{c}{ Table 8: Size /Location of composting area } \\
\multicolumn{1}{c}{$\begin{array}{c}\text { Number of } \\
\text { Size /Location of composting }\end{array}$} & 167 & \multicolumn{1}{c|}{ Percent } \\
\hline $\begin{array}{l}\text { Very small area in the garden less than } \\
5 \mathrm{ft} \text { by } 5 \mathrm{ft}\end{array}$ & 109 & 47.6 \\
\hline $\begin{array}{l}\text { A small area kitchen/garden (eg 5feet } \\
\text { by } 5 \text { feet) }\end{array}$ & & 31.1 \\
\hline $\begin{array}{l}\text { A fairly big area kitchen/garden (10 feet } \\
\text { by } 10 \text { feet) }\end{array}$ & 75 & 21.4 \\
\hline Total & 351 & 100.0 \\
\hline
\end{tabular}

The data collected indicate that the majority of respondents do compost either of food waste or garden waste in the garden or kitchen area. In addition, almost all respondents use the MPSJ composting bin that was given by household requests. However, only $70 \%$ have sent their green waste to the Bio Mass point collection centre in Bukit Puchong, which is in another neighbourhood area.

\subsection{Discussion}

In this study, practice theory elements were constructed as an attempt at studying green human activity. This was conducted upon reviewing previous literature on the subject of civic ecology (Schatzki, 2000, Gram-Hanssen, 2011). However, practice theory scholars diverge on the elements of practice worthy of study (Gram-Hanssen, 2011). This study has attempted to define the relevant details using a quantitative procedure. The findings indicate that there is a significant association $(p<0.05)$ between doing composting with a sociodemography variable, i.e., 'length of stay' while competencies or ability to conduct composting is highly correlated with training, collaboration, communication, and understanding with others. The practice also gives meaning to the respondents/participants such that it is a way to reduce food wastage and provides benefit to the plants and environment. The method is also sustained by motivations from family, creation of friendships, and civic consciousness.

\subsection{Conclusion \& Recommendations}

Other studies rely on more qualitative assessments of civic ecology practice (Krasny et al., 2015), while this study applied a quantitative procedure to extract the elements of green practice. Future research suggests for environmental stewardships evaluation of green practices of different neighbourhood profiles, perhaps with old populated neighbourhoods (Pratiri and Furuya, 2018). This perspective is useful to municipalities' policy planning or that focuses on various environmental practices to enrichen the literature on ecological stewardships.

\section{Acknowledgements}

This study is funded by the UiTM Lestari Research Grant Ref: 600-IRMI 5/3/LESTARI 053/2018.

\section{References}

Cetina et al. (2000). The Practice Turn in Contemporary Theory. Taylor and Francis. 
Goodwin,L.D.(1999) The Role of Factor Analysis in the Estimation of Construct Validity. Journal Measurement in Physical Education and Exercise Science Vol.3, Issue 2.

Gram-Hanssen (2011) Understanding change and continuity in residential energy consumption Journal of Consumer Culture Volume: 11 issue: 1, 61-78

Hargreaves, T. (2011). Practice-ing behaviour change: Applying social practice theory to pro-environmental behaviour change. Journal of Consumer Culture, 11(1), $79-$ 99 .

Kamaruddin, S.M., et al. (2013). Facilitating Social Learning in Sustainable Waste Management: Case Study of NGOs Involvement in Selangor, Malaysia. Procedia Social and Behavioural Sciences.Vol 105, 325-332.

Kamaruddin, S.M., et.al. (2018) Community Awareness on Environmental Management through Local Agenda 21 Procedia Social and Behavioural Sciences.Vol 222, $729-737$

Kamaruddin, S.M., et.al. (2016) Asian Journal of Quality of Life (AjQoL), 3(12) Jul / Aug ,147-155

Kemmis, Stephen \& Mutton, Rebecca. (2012). Education for sustainability (EfS): Practice and practice architectures. Environmental Education Research. 18. $187-207$.

Kline 1994 An Easy Guide to Factor Analysis.Routledge Milton Park.

Krasny, M.E \& Tidball K.G (2015). Civic Ecology. Adaptation and Transformation from the Ground Up. Massachusetts Insttitute of Technology Press.

Krasny, M.E \& Tidball K.G (2018). Grassroots to Global. Broader Impacts to Civic Ecology.Cornell University Press

Prita Indah Pratiwi 1, Katsunori Furuya (2018) Characteristics Of Tokiwadaira Neighbourhood Park In Matsudo, Japan: A Space For The Elderly

Reckwitz, A. (2002). Toward a Theory of Social Practices: A Development in Culturalist Theorizing. European Journal of Social Theory, 5(2), $243-263$.

Rugayah Hashim, Nurul Dalina Mohamad Ristak, Normarliana Laili (2016) Attitudes Toward Environmental Democracy Among Urban Communities EnvironmentBehaviour Proceedings Journal, Vol1 No.3

Seyfang, et al. (2014) A grassroots sustainable energy niche? Reflections on community energy in the UK, Environmental Innovation and Societal Transitions, Volume 13, 2014, 21-44, Warde 2005

van der Schoor, Tineke \& Scholtens, (2015. "Power to the people: Local community initiatives and the transition to sustainable energy," Renewable and Sustainable Energy Reviews, Elsevier, vol. 43(C), 666-675

Warde, A. (2005). Consumption and Theories of Practice. Journal of Consumer Culture, 5(2), 131-153. 